the Food Administration in urging the consumption of these commodities to relieve the pressure upon wheat and animal products. The increased consumption of oleomargarine was no doubt due to a tavourable price in comparison with that of butter and lard.

Prof. Pearl provides a summary of daily consumption per "man," which again brings out the uniformity from year to year. The largest figure is 4361 Calories in $1913-14$, and the smallest 42 II in $1916-17$. The average figures are: 121 grams of protein, 169 grams of fat, and 542 grams of carbohydrate, yielding 4290 Calories. Assuming that 5 per cent. of protein, 20 per cent. of carbohydrate, and 25 per cent. of fat are lost in the wastage of edible substances, the per capita average of ingested food becomes:-Protein, II4 grams; fat, I27 grams; and carbohydrate, 433 grams, yielding 3424 Calories. These final figures are in good accord with the results of dietetic studies both in America and in England. Prof. Pearl justly remarks that "discussions of the minimum protein, fat, and carbohydrate requirements of a nation are in a considerable degree academic if they base themselves upon net consumption rather than gross consumption. A considerable excess over any agreed-upon minimum physiological requirements must always be allowed, because there will inevitably be, in fact, a margin between actual gross consumption and net physiological ingestion or utilisation."

The report is a useful contribution to knowledge. It is to be feared that since the armistice little attention has been devoted to the study of national dietetics in this country. During the war British physiologists made valuable experimental and statistical contributions to the subject; on the statistical side the work of the late Sir William Thompson, and on the experimental side that of Prof. Cathcart and his collaborators, deserve special mention. It is to be regretted that there is little prospect of the foundations then laid being built upon; it will be long indeed before the task of feeding the nation ceases to cause anxiety and to merit scientific elucidation.

M. G.

\section{Engineering Research in the U.S.A.}

THE problem of co-ordinating the interests and activities of the various engineering institutions and societies has been subject to much discussion in this country. In America this problem was largely solved by the establishment in 1904 of the United Engineering Society, which combined the interests of four founders' societies, namely, the American Society of Civil Engineers and the American Institutes of Mining and Metallurgical Engineers, Mechanical Engineers, and Electrical Engineers. The United Engineering Society now numbers some forty thousand members, and its administration comprises three principal departments, namely, the library board, the engineering council, and the engineering foundation. The last-named department is of particular interest, and is directed to the furtherance of research in science and engineering.

The engineering foundation was established as a result of a gift of 200,000 dollars by $\mathrm{Mr}$. Ambrose Swasey, this sum being used as the nucleus of a fund the income of which was to be devoted to research or for the advancement in any other manner of the profession of engineering and the good of mankind. This first gift was made in 1914 , and in September, I9I8, Mr. Swasey added a further sum of 100,000 dollars to the endowment.

The donor is an engineer and manufacturer, and president of the Warner-Swasey Co., of Cleveland, Ohio, a firm manufacturing fine tools and astro. NO. 2645 , VOL. IO5] nomical and other instruments of precision. $\mathrm{Mr}$. Swasey is a member of most of the American engineering societies, and of several English scientific societies, including the Royal Astronomical Society. $\mathrm{He}$ is the author of a number of papers read before American engineering societies.

For all practical purposes the engineering founda tion is a professional trust organised along the lines of the Carnegie, Rockefeller, and Sage foundations. The facilities it provides have heretofore been devoted principally to engineering research, and its most notable work has been conducted through co-operation with the National Research Council, which is an organisation of men of science, engineers, and educators brought into being by the National Academy of Science at the request of President Wilson in 1916 , and employed largely in the conduct of scientific investigations relating to anti-submarine and other war problems.

When the National Research Council was formed the administrators of the engineering foundation made themselves responsible for its financial support for a period of one year, and this brought into successful co-operation a body of engineering and scientific men in a comprehensive and practical manner.

Since July, I9 9 , the research work undertaken by the foundation has been of a very comprehensive nature. It has included, for example, preliminary researches on such subjects as a new hardness testing machine, the elimination of casting defects from steel, the uses of cadmium, the uses of alloy steels, Neumann bands in iron and steel, the heat treatment of carbon steel, electrical insulation, and substitute deoxidisers. A sum of I5,000 dollars a year for a period of two years has been voted for the conduct of research in the fatigue phenomena of metals in the laboratories of the engineering experiment station of the University of Illinois. From approximately fifty suggested subjects, the engineering foundation has also selected for investigation: (I) The wear of gears, (2) spray camouflage for ships, (3) the directive control of wireless communication, (4) weirs for the measurement of water, (5) the establishment of a testing station for large water-wheels and other large hydraulic equipment, and (6) the mental hygiene of industry.

These investigations are now all in progress or have been completed. Particular attention has been given to research relating to mental hygiene in industry, the objects of the research being to develop or discover methods for adapting psychopathetic individuals to usefulness in industry.

Realising, further, that mental hygiene dealt with only one of the many elements of the industrial personnel problem, the foundation board, in association with the National Research Council, arranged for the appointment of a committee representative of anthropology, psychology, educational relations, industrial relations, engineering, and medicine to consider means for furthering the study of the problems of industrial employment.

Quite apart from such efforts, the engineering foundation has interested itself in an attempt to coordinate the activities of many of the very numerous societies and associations, some local, some national, having a bearing on engineering, and to harmonise their relations and aims. Up to the present, however, no active investigational work along these lines has been undertaken. While the foundation maintains the closest relationship with the divisions of engineering of the United Engineering Society and the National Research Council, it reserves the right to conduct under its own immediate direction such researches as may commend themselves to its membershio. 
The administration of the engineering foundation is conducted by sixteen members elected by the United Engineering Society, thirteen of whom must be members of the founder societies. Although finally organised only in the early part of 1915 , the foundation has become thoroughly established, and is carrying on a most admirable work.

\section{A. P. M. Fleming.}

\section{African Softwoods for Pulp Production.}

\author{
By A. H. Unwre,
}

Late Senior Conservator of Forests, Nigeria.

$A$ BOUT the year 1907, at the instigation of the late A Sir Alfred Jones, an inquiry was addressed to the West African Colonies with regard to the softwoods suitable for paper or pulp production. As a result a list was compiled for the Benin country, which included some twenty species of whitewood. Since that date little or nothing has been done towards the solution of this problem. Nevertheless, much greater knowledge has been obtained of the softwoods of the West Atrican Colonies-the Gambia, Sierra Leone, Gold Coast, Nigeria-and of West Africa generally.

Although baobab (Andansonia digitata) has been suggested as suitable, it is usually found rather remote from navigable waterways, and in such scattered quantities that it is doubtful if its exploitation will pay. On the other hand, the wood of the cotton-tree, Eriodendron anfractuosum and $E$. orientale, has been adversely reported upon, but it does not appear that very exhaustive experiments were made with either of these species. The ease of its production, the rapidity of its growth, and the softness of its wood would seem to commend the cotton-tree for pulp production. The wood of Bombax buonopozense may also be of use.

Perhaps a more suitable wood will be obtained from the African maple, Triplochiton Johnsonii and $T$. nigericum. The wood of both these species is of about the same hardness as that of spruce. It is of a similar colour, and the fibres are long. The tree is very prevalent, its reproduction easy in the proper localities, and its growth rapid. On average soil the trees reach pulp-wood size within ten years, and there are many specimens even in seven years.

In certain localities the occurrence of Sterculia Barterii is such as to redden the hill-sides with its flowers in March. The growth of the tree is very rapid, and the wood is fibrous and porous. The tree will attain pulp-wood size in five vears. In suitable localities the natural reproduction from mature trees is rapidly filling the whole forest.

Other Sterculiæ, such as tomentosa. rhinopetala, and tragacantha, might be used. Of these the lastnamed appears to be the most suitable. It is also very prevalent, and grows rapidly. The wood of Sterculia rhinopetala may prove to be a little hard, but with modern means of pulping it may be possible to use all these species at the same time.

The quantity of bamboo on the West Coast of Africa is negligible though the area of its distribution is gradually widening.

The Albizzias usually produce in their younger stages a whitish-yellow softwood. Most species grow very fast, and would yield pulp-wood within ten years. The wood shows long fibres. Owing to the prevalence of the tree in the forests, there would be no difficulty as to the quantity. The wood of Terminalia superba should prove of value, though its brownish tinge mav have to be removed in order to make the best-coloured pulp. It is prevalent and its growth is rapid.

Another very common tree is Alstonia congensis, NO. 2645 , VOL. IO5] which is often found in the swamps as well as in the moist forests. Its growth is very rapid, and it would yield pulp-wood in seven years. Owing to its prevalence, this softwood with its longish fibre should prove of value.

The wood of Ricinodendron Heudelotti appears to be suitable, though the colour is dull grey-brown. The tree is very prevalent, and its natural regeneration prolific. It reaches pulp-wood size within a period of seven to ten years. Pycanthus kombo is another tree which appears to yield a suitable species of timber. It is very prevalent, the wood is soft and fibrous, and natural reproduction is great. Even the much-despised Musanga Smithii might on occasion be used to supplement inadequate supplies of other pulp-wood timbers. Near the rivers in some districts there is a common tree named Otu, which is planted by the natives. It yields a soft whitewood which has a longish fibre.

With the great shortage of paper-pulp it appears that the utilisation of these West African species of trees should be undertaken as soon as possible. Naturally, it will mean a good deal of experimental work, but with the experience already gained in Canada and. Norway and Sweden it should be possible to produce pulp below existing cost. Although African labour is expensive as compared with Indian or Burman, it has proved itself thoroughly adaptable to training in the use of complicated machinery such as that employed in shipbuilding and in oil-and saw-mills.

With a population of about sixteen millions of people in Nigeria alone, it has been found possible gradually to obtain sufficient men for a new industry.

\section{Effect of Topography on Precipitation in Japan.}

CONSIDERABLE attention has been directed recently to the subject of the orographical distribution of rainfall, and results obtained in different places are liable to lead to general deductions, not only independent, if not quite contradictory, but also, on the face of them, improbable. We may instance an alleged connection between Indian monsoon intensity and the extent of local water surfaces, and also M. Mathias' cartographical demonstration that the increase of precipitation with altitude is directly dependent on the latitude, at any rate in France. $\mathrm{Mr}$. Carle Salter's lecture to the Institution of Water Engineers on the relation of rainfall to configuration gave little ground for suspecting either of these possibilities.

At first sight, Prof. Terada's contribution in the Journal of the College of Science, Tokyo Imperial University (vol. xli., art. 5), appears to be only a supplement to previous work of Profs. Nakamura and Fujiwhara, but one or two comparatively fresh notes are struck. Prof. Omori had previously found a correlation between earthquake frequency in some districts and precipitation in others. This is now described by Prof. Terada as a case more of parallelism than of cause and effect, for he prefers to attribute both phenomena to barometric changes rather than to associate the instability of the soil with percolation. His main purpose, however, is to study the effect of the discontinuity of wind velocity on land and sea, and for this purpose he divides Japan into six districts, three facing the ocean and three the Japan Sea, and in each district chooses two or three stations near the coast.

The three "ocean" divisions show a marked increase in rainfall with decreasing latitude, but on the con- 